\title{
The Political Economy of the United States in the Era of Hatred and Partisan Polarization
}

\author{
Oluwole Owoye, Ph.D. \\ Professor of Economics \\ Department of Social Sciences/Economics \\ Western Connecticut State University \\ Danbury, CT 06810
}

\begin{abstract}
This paper uses conceptual economics to analyze the consequences of the rising racialgender hatred and partisan polarization on the political economy of the United States. The upsurge in hate crimes nationwide is due to the politicians' peddling of hatecreating stories and false narratives. This paper identifies and discusses the three interdependent institutions through which hatred and partisan polarization could destabilize the political economy; and tests whether the increasing racial-gender hate crimes, partisan polarization, and government shutdowns have adverse effects. The statistical tests confirm the research hypotheses about the rising racial-gender hate crimes; and that partisan polarization and government shutdowns have negative effects on Congressional productivity in the United States.
\end{abstract}

Keywords: Political economy, racial-gender hatred, partisan polarization, institutions, Democrats, Republicans.

\section{INTRODUCTION}

The analysis of the political economy is complicated if we consider the most powerful country in the world, the United States, where growing racial-gender hatred and intense partisan polarization could impede the governance and the effectiveness of its major institutions; and this may have a very strong ramification on representative democracy in the United States and around the world. If the rising waves of racial-gender hatred and partisan polarization altered the political economy of the United States - the standard-bearer of the global political economy - one wonders the message it conveys to newly emerged and emerging representative democracies worldwide.

The contribution of this study lies in its attempt to use of relevant interdisciplinary studies approach to analyze the various institutions through which racial-gender hatred and partisan polarization affect the political economy of the United States, a country most recognized and revered in the world for its representative democracy. For the past five or more decades, studies have attributed racial-gender hatred to politicians who supply hate-nurturing stories to hate groups within the electorate through the repetitions of false narratives, and that there are external and internal causal factors with respect to partisan political polarization in the United States.

Another contribution of this study is its application of the concept of revealed preference to show that in the current political environment where politicians from both parties peddle endless hate-creating stories and false narratives about the other groups and other countries, hate groups now have the domestic and international platforms on which to unleash their overt racial-gender and global hatred. This is important because the President of the United 
States (POTUS) has consistently accused our allies as "free riders" and exploiters in global alliances and trade. In addition, I use a simple game theoretic framework to show that Democrats (DEM) and Republicans (REP) are players in a political game of tit-for-tat; therefore, the retaliatory tendencies from both parties will exacerbate overt hatred and partisan polarization into the foreseeable future. Since both parties are scared of the REPPOTUS and are afraid to enforce the rule of law and all political norms, the complicity would enable the unchecked dictatorial propensities to undermine representative democracy and destroy global alliances that relied of the United States' leadership since World War II.

As further contribution to the literature, this paper identifies three categories of interdependent institutions - economic, political, and social - through which I examine the effects of overt racial-gender hatred ${ }^{1}$ and partisan polarization on the political economy and representative democracy in the United States. To date, researchers have not examined whether hate crime laws pre- and post-the Hate Crime Prevention Act of 2009 were effective in reducing hate crimes or analyze the effects partisan polarization on the three interdependent institutions in a representative democracy. There is no doubt that strong economic, political, and social institutions are pivotal in nurturing the growth and sustainability of representative democracy; therefore, the contention is that the growing racial-gender hatred and partisan polarization would weaken these institutions, global alliances, and thus undermine representative democracy and the political economy of the United States.

Another contention is that in this era of growing overt racial-gender hatred and extreme partisan animosity characterized by toxic tribal politics, it appears that Congressional Democrats and Republicans are too reluctant to perform their Constitutional duty of providing the required checks and balances. In doing so, they are enabling a REP-POTUS or a DEM-POTUS to weaken the institutional (economic, political, and social) bedrocks of representative democracy in the United States. This implies that a REP-POTUS or a DEM-POTUS can contribute to and normalize overt racial-gender hatred and partisan polarization in order to deconstruct and undermine the basic principles of representative democracy; and this could lead to a monarchial, an authoritarian, or an oligarchical "democracy" that exists in other countries. This study argues and shows that this will have adverse effects not only on the political economy of the United States, but will also diminish its leadership roles in the global political economy, thus ushering in an era of international turmoil.

At the outset, I discuss the relevant background perspectives on hatred and political polarization, and then provide a conceptual model of revealed preference of hate groups in addition to a tit-for-tat game model to explain the retaliatory tendencies between Democrats and Republicans in their political interactions, which will continue to exacerbate overt hatred and partisan polarization into the foreseeable future. I discuss the effects of hatred and partisan polarization on the economic, political, and social pillars of representative democracy in the United States and provide the methodology and estimated results, and finally conclude with political implications.

\section{BACKGROUND PERSPECTIVES OF HATRED AND POLITICAL POLARIZATION}

Research scholars have employed a number of methodologies such as statistical analysis of large data, participant observation, and historical research to examine two important complementary issues: racial-gender hatred by hate groups and extreme political polarization in the United States. According to some historians such as Woodward (2002), the press

${ }^{1}$ See Glaeser (2005) for a detailed discussion of the "political economy of hatred." 
sensationalized false crime stories of the Black race, which fostered racial hatred in the Postbellum South. In a seminar paper about the political economy of hatred, Glaeser (2005) develops a model to illustrate the interaction between the politicians who supply hate-creating stories as well as false narratives and the willingness of voters to consume hatred. According to Glaeser (2005), politicians foster hatred by peddling false stories about the crimes committed by the other groups because the susceptible hate groups willingly accept these false stories without any investigation, and that "the impact of these stories come from repetition and not truth."

According studies and reports by Fischer (2016), Dreid and Najmabadi (2016), Quintana (2017), Kerr (2018), and Bauman (2018), anti-Semitic vandalism and white-nationalist propaganda are on the rise at colleges and universities nationwide. Bauman (2018) pointed out that the new information from the United States Department of Education revealed that the number of hate crimes increased by 25.5 percent from 2015 to 2016 and that the election of 2016 played a role in the upsurge of hate crimes across colleges and university campuses nationwide. The consensus among these studies is that white supremacists hate groups are targeting college and university campuses like never before to the point that whitesupremacists hate groups such as Identity Evropa, Patriot Front, and Vanguard America have increased their propaganda by 258 percent at colleges and universities during the 2016-2017 academic year. According to Kerr (2018), Jonathan Greenblatt - the Anti-Defamation League's chief executive - believes that the hate groups see campuses as a fertile ground to recruit young people to support their vile ideology.

With respect to the issue of extreme partisan polarization, studies have also used different methods with which they identified different internal and external causal factors. ${ }^{2}$ For the internal causal factors, studies attributed partisan polarization to procedural rule changes, majority-party agenda control, party pressures, teamsmanship, and the breakdown of partisan norms. Studies by Roberts and Smith (2003), Roberts (2007), Theriault (2008a), and Shor and McCarty (2011) argued that rule changes have made it easier for amendments to be proposed when considering legislation thereby forcing the opposition party to cast unpopular votes in order to move on with the main piece of legislation, thus aggravating the partisan differences and ultimately polarization.

According to Rohde (1991), Aldrich (1995), Cox and McCubbins (2005), and McCarty et al. (2006), the leaders of the majority party in both the House and the Senate have used the power of their gavel to control the legislative agenda in order to build party loyalty, thus leading to party-line votes and increased polarization. In the views Rohde (1991), Snyder and Groseclose (2000), McCarty et al. (2001), Theriault (2008b), and Edwards (2012, the party leaders in the House and the Senate use the power vested in them to apply stronger pressures on members to vote party lines, either by coercion or by offering rewards in terms of committee membership and/or chairmanship.

Gilmour (1995), Groseclose and McCarty (2001), and Lee (2009) consider teamsmanship as an internal causal factor of partisan polarization, which forces the two parties to become more competitive in seeking control of national agenda. The result is the desire to differentiate one party from the other thus forcing both parties to engage in strategies of confrontation in order to highlight their partisan differences at the national stage in order to garner the attention of the electorate. With respect to the breakdown of partisan norms, Eilperin (2007) argues that

2 See Rhode (1991), Sinclair (2006), Hacker and Pierson (2006), Mann and Ornstein (2012), McCarty, Poole, and Rosenthal (1997, 2006), Poole (2007), and Lee (2009). 
members of Congress spend more time on fundraising in their districts and less time in Washington, thus they are unable to build partisan and bipartisan coalitions, trust and civility within and across party lines.

For the external causal factors of political polarization, studies attributed partisan animosity to an extremely polarized electorate, unabated district gerrymandering, primary elections, economic or income inequality, money in politics, and the media environment. Many studies such as McClosky et al. (1960) and others ${ }^{3}$ argue that legislators at various levels of government behave in ways that reflect the preferences of their constituents, who are themselves polarized; and some of whom belong to hate groups with the willingness to listen to and consume hate-creating stories from their elected politicians, especially the POTUS. According to Tufte (1973), Carson et al. (2007), Theriault 2008), McCarty et al. (2006, 2009), the unabated gerrymandering of congressional districts enabled State legislatures to draw partisan districts that enabled members of Congress to remain in office by suppressing the voting rights of minorities rather than competing for votes at the political center.

Kaufman et al. (2003), McCarty et al. (2006), Hirano et al. (2010), Bullock and Clinton (2011), McGhee et al. (2014) argue that the both parties have moved from closed partisan primaries to open primaries, which allow the participation of independents. According to Brewer et al. (2002), Piketty and Saez (2003), McCarty et al. (2006), Bartels (2008), Gelman (2009), Garand (2010), Gilens (2012), and Bonica et al. (2013), the increase in income inequality is highly correlated with political polarization. Studies such as Hall and Wayman (1990) contend that partisanship and polarization have direct link to the current system of private campaign finance used in United States elections. The basic premise is that politicians pursue the policy objectives on behalf of their special-interest donors who are, essentially, the referees in political games and legislative outcomes. ${ }^{4}$ Finally, other studies [Groseclose and Milyo (2005), Gentzkow and Shapiro (2006), Zeliner (2006), DellaVigna and Kaplan (2007), Prior (2007), Gerber et al. (2009), and Snyder and Stromberg (2010)] argue that changes in the media environment of politics, specifically since the Watergate scandal and the advent of cable news networks and social media played an important role in partisan polarization.

Four symposium articles in Polity, Volume 46 (3), highlighted and discussed the significance of partisan polarization and American democracy. In summarizing these symposium articles, Ladewig (2014) highlights the main premise of the lead article by Christopher Hare and Keith T. Poole in which they argue that "the level of partisan and ideological polarization between the two major American parties is as high as it has been any time since the Civil War." Furthermore, Hare and Poole (2014) pointed out that the passage of the Civil Rights Act of 1964 and the Voting Rights Act of 1965, which changed the voting direction of Southern Whites contributed to the modern trend to greater partisan polarization. ${ }^{5}$ According to Hare and Poole, Southern Whites began to vote for Republican candidates as the process of issue

${ }^{3}$ Others studies are by Poole and Rosenthal (1984), Bartels (2000), Layman and Casey (2002), Sunstein (2002), Klinkner (2004), Fiorina et al. (2005), McCarty et al. (2006), Carsey and Layman (2006), Clinton (2006), Ansolabehere et al. (2006), Fiorina and Abrams (2008), Levendusky et al. (2008), Levendusky (2009), Gelman (2009), Bishop (2009), Abramowitz (2010), Bafumi and Herron (2010), Layman et al. (2010), Lenz (2012), Shaw (2012), and Fiorina (2013).

${ }^{4}$ For more studies, see Jacobson (1990), Baron (1994), Smith (1995), Ansolabehere et al. (2003), Moon (2004), McCarty et al. (2006), Gimpel et al. (2006, 2008), Ensley (2009), Bafumi and Herron (2010), Stone and Simas (2010), Lessig (2011), Bonica (2013), and Barber (2013).

${ }^{5}$ Both parties view liberalism and conservatism from a combination of three different issues and lenses: economic, political, and social, which have resulted in different types of partisan sorting among Congressional Democrats and Republicans as well as the electorate. 
evolution over race played out. In Ladewig's opinion, the findings of the second symposium article by Tracy Sulkin and Carly Schmitt "dovetail with and reinforce the conclusions of Hare and Poole, including finding very high levels of polarization alongside some intraparty divisions."

In Ladewig's summary of the third article by Monika McDermont and Cornell Belcher (2014), he notes that both authors "offer another analysis of the enlarging issue scope" and that "they are particularly interested in the role that race has played during and after the unprecedented elections of America's first African-American president, Barack Obama. The authors find that racial antagonism among white Democrats dropped significantly immediately after Obama's 2008 victory, and that afterwards white Democrats' racial antagonism remained significantly lower than was white Republicans' racial antagonism. This provides further evidence of an expanded issue scope-at the mass level-upon which modern polarization is built." In the final summary of the last symposium article by David Jones, Ladewig asserts that Jones (2014) "explores a vastly under-examined phenomenon: the changing electoral consequences of the parties in a polarized political environment based on their party majority or minority status in the Congress." More importantly, Jones "theorizes and then demonstrates through analyses of public-opinion surveys that, at the current levels of polarization, the public now forms and uses separate evaluations of congressional performance for each party." Ladewig concludes, "None of the articles in this Symposium foresees a reduction in polarization over the foreseeable future."

A recent study by Owoye and Dabros (2017) identified another causal factor as manifested by the current political landscape. They argued that the White House Occupant (WHO), which could be a Democrat (DEM) or a Republican (REP), would exacerbate partisan polarization into the near future because Republicans harbored racial and policy resentments against the past WHO-DEM, and in retaliation, Democrats now harbor policy resentments against a WHO-REP.

\section{THE INCREASING RACIAL-GENDER HATRED AND PARTISAN POLARIZATION}

Glaeser's (2005) model highlights the relationship between those politicians who supply hatecreating false stories with the intention to discredit the other groups and the willingness of hate groups and racist individuals from both parties to consume the hatred-laden false stories without verification. He also points out that the hate-creating stories of the crimes committed by the other groups tend to feed into the beliefs and practices of the various hate groups and that the impact of these stories comes from the repetitions of the false narratives about the other groups. ${ }^{6}$ This section takes a related route using simple conceptual economics for illustrative purposes.

\section{The Model of Hatred}

This model highlights that racial-gender hate groups who engage in covert and/or overt hatred exist in all countries at varying degrees. In the United States, the intensity of hatred is magnified by the political ideologies of the Democratic and Republican parties to which these hate groups belong because "Hatred can be a tool of either the left or the right" - see Glaeser (2005). Historians and pundits show that overt racial-gender hate groups existed nationwide before and after the passages of the Civil Rights Act (CRC) of 1968, Violent Crime Control and Law Enforcement Act (VCCLEA) of 1994, Church Arson Prevention Act (CAPA) of 1996, and the Hate Crimes Prevention Act (HCPA) of 2009. These hate crime laws forced many of these hate

${ }^{6}$ According to the Southern Poverty Law Center (SPLC), hate groups across the United States have risen from 917 in 2016 to 954 in 2017. The SPLC defines hate groups as organizations with beliefs and/or practices that demonize a class of people. 
groups to reduce their overt racial-gender hatred because of the legal penalties for such behavior. The central question is: Where are we in the current political environment in terms of overt hatred?

To answer this question, this study agrees with Glaeser (2005) and asserts that politicians are the principal suppliers of hate-creating stories while hate groups are the consumers and propagators of repeated hate-creating stories and false narratives. These hate groups represent a fraction of the population or electorate, and they maximize their utility $(U)^{7}$ by engaging in covert and overt racial-gender hatred based on their parties' political ideologies. Since the passages of hate crime laws, they face legal costs for such conduct. The hate-utility function is expressed as:

subject to

$$
U=f(C R H, O R H)
$$

$$
T C H=C R H+(+) O R H
$$

where TCH stands for the total costs to hate groups with propensities for covert and overt racial-gender hatred, $\mathrm{CRH}$ stands for covert racial hatred and is the price to those hate groups that engage in covert racial-gender hatred, and ORH is overt racial-gender hatred with

as the price paid to print hate pamphlets and other hate-spreading tools. In addition, $\Omega$ represents the legal penalties stipulated in the CRC, VCCLEA, CAPA, and HCPA for hate groups who engage in overt racial-gender hatred. The research question is: Were these hate crime laws vigorously enforced and effective?

Before HCPA in 2009, hate groups face little or no legal penalties, despite CRC, VCCLEA and CAPA, thus line XY in Figure 1 shows the downward negatively sloped iso-hatred line; and this implies that $\mathrm{CRH}$ and ORH could be any combination along line XY. With $\Omega \approx 0$ prior to HCPA in 2009 , hate groups maximized their utility by consuming zero $\mathrm{CRH}$ and all $\mathrm{OR}_{\mathrm{A}}$ at point $\mathrm{A}$. With the rigorous enforcement of legal penalties since the passage of HCPA of $2009, \Omega>>$, line XY rotates inward to line $\mathrm{XZ}$ and this means $+>>$; therefore, many hate groups reduced their penchant for overt racial-gender hatred. In other words, the legal costs stipulated in HCPA of 2009 forced many hate groups in the United States to reduce overt hatred as shown by point B. From the available data obtained from the Federal Bureau of Investigation, the annual average hate crimes Before-HCPA was 7,933 (point A), and After-HCPA, ORH decreased to 6,079 (point B) due to the legal penalties.

When the current REP-POTUS announced his candidacy for president in 2015, he made racial comments about Mexicans immigrants. ${ }^{8}$ The Republican Party did not condemn him as their presidential nominee in 2015 for his racial-gender overtones despite the fact that the Speaker of the House classified his comments as "textbook racism." Since then, hate groups have shown revived energy to reveal their true preference for overt racial-gender hatred, nationwide. Now that the Republicans control both chambers of Congress and the White House, these hate

\footnotetext{
7This simple methodology is used based on Ellenberg's (2001) argument that any model or "statistical method is fundamentally sound if only it tells you things you already know." The models used in this paper tell us everything that we know during the current and previous administrations. See "Growing Apart: The Mathematical Evidence for Congress' Growing Polarization" at www.slate.com/articles/life/do_the_math/2001/12/growing_apart.html. 8The stereotyping of Mexican immigrants lends credence to the assertion that politicians are the principal peddlers of false stories to their agents (hate groups) about the other group through repetitions - see Glaeser (2005).
} 
groups and other racist individuals are now emboldened to reveal their true preference once again for overt racist propensities. Arguably, these hate groups and racist individuals see REPPOTUS as a tacit endorser of their renewed propensities for racial-gender hatred, which they interpret as an implicit reduction in the legal penalties depicted by line XZ rotating out to line $\mathrm{XK}$ with zero $\mathrm{CRH}$ and all $\mathrm{OR}_{\mathrm{C}}$ at point $\mathrm{C}$. According to the FBI Hate Crime Statistics, ${ }^{9}$ there were 6,121 (depicted as point C) hate crimes committed in 2016 - an increase in ORH from point B to point $\mathrm{C}$.

These hate groups and other racist-individuals prefer to return to the era when there were little or no legal penalties for engaging in overt racial-gender hatred. This paper contends that the current political environment enables the most powerful political leader, the current REPPOTUS, to peddle hate-creating stories and false narratives about the other groups and other countries - even denigrate the African continent - which hate groups consume without verification.

Figure 1: Overt Racial-Gender Hatred Before- and After-HCPA of 2009

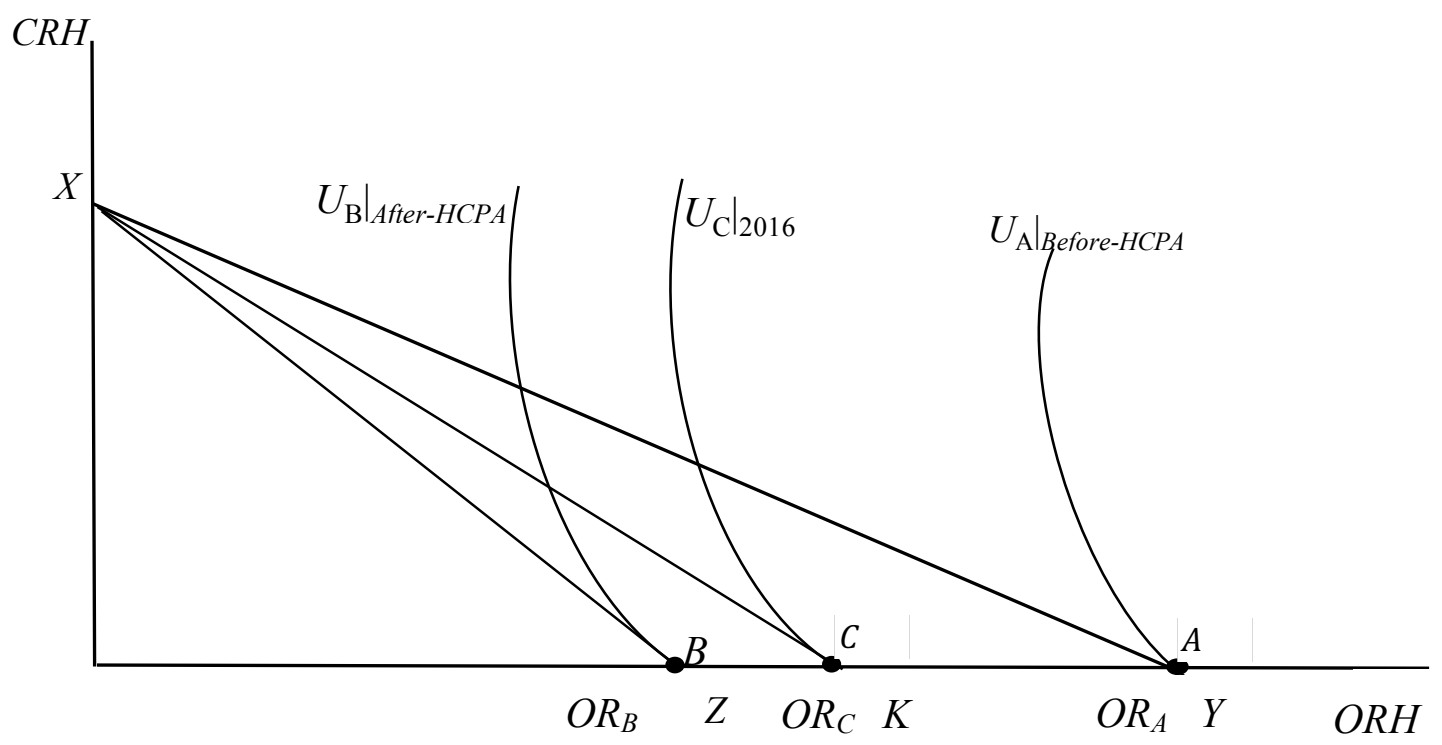

Today, hate groups and racist individuals see the actions of the current REP-POTUS as signaling tacit approval and normalization of racial-gender hatred in the United States. When the current REP-POTUS and some politicians from both parties embolden and condone overt racial-gender hatred, this will exacerbate tribal-racial politics and partisan animosity with adverse consequences on representative democracy in the United States thus leading to negative "demonstration effects" around the world.

\section{Game Theoretic Explanation of Partisan Polarization}

According to Sulkin and Schmitt (2014), there is a growing consensus about the causes of partisan polarization between Democrats and Republicans, but that we know much less about its consequences, especially how polarization has or has not affected other components of legislative activity, such as the issue agendas individual members of Congress pursue in their introduction and co-sponsorship of legislation. Sulkin and Schmitt (2014) focused on the individual level by discussing three interrelated issues. First, the degree of partisan polarization in the main agendas of both Democrats and Republicans and whether they devote their time and effort to different issues. Second, the increasing partisan differentiation in

${ }^{9}$ For the data on FBI Hate Crime Statistics, see https://ucr.fbi.gov/hate-crime. 
agendas by both parties between the late 1980s and 2000s. Third, whether the moderate and liberal Democrats or moderate and conservative Republicans differ systematically in their agendas and the degree of these differences overtime.

To comprehend the consequences of partisan polarization on the political economy of the United States, this paper provides a game theoretical framework to highlight the irrationality underlying the strategic behaviors of Congressional Democrats and Republicans in a united or a divided Congress. Since the political economy encompasses the production and trade in relations to the rule of law, custom and government as well as the social welfare; therefore, one can view the political economy from three categories of interdependent institutions: economic, political, and social in order to understand the consequences of partisan polarization on these institutions. To analyze the underlying factors with respect to why partisan polarization would continue into the foreseeable future, this paper shows the political interactions between Democrats (DEM) and Republicans (REP) in Congress in a game theoretic framework. In a strong bipartisan political environment, POTUS and Congress can achieve high legislative productivity or low legislative productivity in an extremely vitriol partisan polarized environment.

Wherever two or more political parties exist and these parties are aware that their legislative proposals are determined through bipartisan coalitions, they are players in a political game with each other. For simplicity, assume that the POTUS has some sets of policy agenda, which he/she campaigned on during an election cycle and that the objective of the POTUS and members of his/her party in Congress is to pass useful bipartisan pieces of legislation proposed by the POTUS and his or her party. In addition, let $\alpha$ and $\lambda$ represent the percentage of the current 242 Democrats and 286 Republicans who can support the POTUS and his or her party's legislative agenda, while $(1-\alpha)$ and $(1-\lambda)$ represent the percentage of those from both parties who oppose the POTUS and his or her party's legislative agenda. ${ }^{10}$

Let $S_{i}$ be the strategy space for DEM and REP and that both parties have the set of strategies $s_{i}=$ Support, Oppose available, and each party knows about the previous actions of the other party; therefore, the strategy tells both parties how to react to the actions of the other. The dominant strategy for both DEM and REP $\left[s^{*}\left(s_{D E M}^{*}, s_{R E P}^{*}\right)\right]$ is the best response to any strategy the other party chooses, even when such actions by the other party are considered to be very irrational..$^{11}$ If both DEM and REP choose Support, Support strategy profile in support of the legislative proposal of the POTUS, then, the outcome is a case of bipartisan support with the payoffs of $\lambda(286), \alpha(242)$, which means $\lambda=\alpha=1$. Any REP-POTUS or DEM-POTUS will prefer this outcome because it enhances effective governance pivotal for representative democracy and forces both parties to compete on party differentiation thus forcing both parties to campaign on strong economic, political, and social issues in order to win the support of the voters. For simplicity, let us assume that there are occasions in which both DEM and REP choose the Oppose, Oppose strategy profiles for a variety of reasons with the payoffs given as (1 $-\lambda) 286,(1-\alpha) 242$. In the Oppose, Oppose strategy profiles, $\alpha=\lambda=0$ implies total bipartisan

\footnotetext{
10 Currently, there are 286 Republicans, 240 Democrats, 2 Independents and 7 open/vacant seats in Congress. Adding the two Independents who generally vote with Democrats yields the 242 Democrats used in this illustration.

${ }^{11}$ It is obvious that the dominant strategy of the Democratic Party since President Trump's inaugural is Oppose; therefore, one can predict that the Republicans will reciprocate the next time a DEM-POTUS occupies the White House.
} 
opposition to the POTUS in cases such as the overriding the POTUS' veto, the unpopular tariffs trade policy, and the "zero tolerance" immigration policy.

The case of political polarization can be depicted if for a REP-POTUS, Republicans choose Support with a payoff given as $\lambda(286)$ and Democrats choose Oppose with a payoff given as (1$\alpha) 242$ because they oppose the policy positions of the REP-POTUS. Interpretatively, let $\lambda=1$ and $\alpha=0$, and this yields $286>242$. This also holds true if a DEM-POTUS occupies the White House and his/her party holds the majority in both chambers of Congress and Democrats choose Support with payoff given as $\alpha \times$ majority, and in retaliation, Republicans choose Oppose with a payoff given as $(1-\lambda) \times$ minority. If $\alpha=1$ and $\lambda=0$, this yields majority > minority. Both scenarios show a REP-POTUS and/or a DEM-POTUS passing his/her legislative agenda only through partisan majority support. ${ }^{12}$ In other words, REP and DEM alternate ${ }^{13}$ Support, Oppose with Oppose, Support in a tit-for-tat strategy profiles. The problem with this alternation is that it may continue into the foreseeable future such that for a POTU-REP and a DEM-POTUS, $\alpha$ and $\lambda$ will be consistently equal to zero, respectively, and this therefore means that major legislation will be passed by a partisan majority. For this repeated political game situation, the payoffs ${ }^{14}$ are summarized in Table 1, which shows two important strategy profiles: Support, Support and Oppose, Oppose.

If $\alpha=\lambda=1$, the Support, Support strategy profiles in cell I will be superior to the Support, Oppose in cell II; and the Oppose, Support strategy profiles in cell III are also superior to the Oppose, Oppose strategy profiles in cell IV. Essentially, the Support, Support and Oppose, Oppose strategy profiles are the best and the worst possible outcomes in terms of the sum of payoffs, respectively. The payoffs given as $(1-\lambda) 286,(1-\alpha) 242$ generated by the Oppose, Oppose

Table 1: The Congressional Political Game between Democrats and Republicans

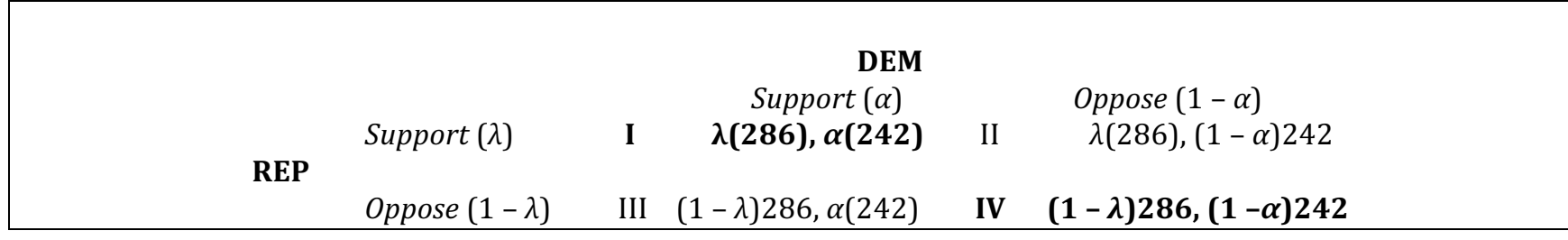

strategy profiles can be considered to be Pareto-inferior when compared to the Paretosuperior payoffs given as $\lambda(286), \alpha(242)$ generated by the Support, Support strategy profiles, which is considered to be the Nash equilibrium. Essentially, when $\alpha=\lambda=1$, the Support, Support strategy profiles as the Nash equilibrium Pareto-dominates the Oppose, Oppose strategy profiles when $\alpha=\lambda=0$.

\section{THE CONSEQUENCES OF HATRED AND PARTISAN POLARIZATION}

This section examines the consequences of hatred and partisan polarization on the political economy of the United States through the interdependent economic, political, and social

\footnotetext{
12The Patient Protection and Affordable Care Act (PPACA) of March 23, 2010 under President Obama and the Tax Cuts and Job Act of December 22, 2017 under President Trump are two illustrative examples of legislations passed with only majority partisan support.

${ }^{13}$ The tit-for-tat or retaliatory behavior from both parties has a multiplier effect as reflected in many areas of government including shutdowns. For example, there were five shutdowns under President Carter (DEM-POTUS), which averaged 1.25 per year and eight shutdowns under President Reagan, which averaged one per year - see Table 2 .

14The expected outcome for $R E P$ is $\lambda[\alpha+(1-\alpha)]+(1-\lambda)[0(\alpha)+0(1-\lambda)]=\lambda$ and for $D E M$, the expected outcome is $\alpha[\lambda+(1-\lambda)]+(1-\alpha)[0(\lambda)+0(1-\lambda)]=\alpha$; therefore, any POTUS or Congress would want $\alpha=1$ and $\lambda=1$, which is total bipartisan support that would enhance Congressional legislative productivity.
} 
institutional pillars of representative democracy that are most likely to be adversely affected and/or undermined, and which research scholars have not paid attention to or identified until now. The main questions for analysis are: What are the consequences of hatred and partisan polarization on the three interrelated institutional pillars of representative democracy if an emboldened REP-POTUS or a DEM-POTUS demonstrates dictatorial propensities and his/her party members are willing to normalize such behavior? Will the normalization compromise the rule of law and undermine the Constitution of the United States because their primary objective is to maintain control of Congress and the White House? One of the main contentions is that there are dire consequences on many important institutions in the United States due to hatred and partisan polarization if a REP-POTUS or a DEM-POTUS engages in policies of isolationism through the abandonments of or exits from previously negotiated international alliances. This is also true if the United States engages in trade wars, "zero tolerance" immigration policy, and entry bans based on religious affiliation. Let us examine the potential consequences.

\section{The Effects of Hatred and Partisan Polarization on Economic Institutions}

Last year, the current REP-POTUS withdrew the United States from the Trans-Pacific Partnership, which the Obama's administration negotiated in 2016. He continues to contemplate withdrawing from the North American Free Trade Association (NAFTA), negotiated between the United States, Canada, and Mexico during the Clinton's administration in 1993. Recently, he unilaterally imposed a 25 percent tariff on steel and 10 percent on aluminum imported into the United States from a number of countries including Canada and Mexico - our NAFTA partners. Arguably, the REP-POTUS takes these unilateral economic policy actions because he realizes that in a partisan polarized Congress, Republicans have no choice but to follow the party line and support his policy agenda. When a REP-POTUS exhibits authoritarian propensities with respect to trade policies because the Congress and the electorate are ideologically polarized, this would prevent Congressional oversights and may lead to dire economic consequences such as a trade war. Figure 2 - a commonly used textbook diagram in economics ${ }^{15}$ - provides the illustrations of the economic consequences of the current ongoing tariff-restricted trade policy actions of the REP-POTUS. For clarity, I use a three-step approach to illustrate the impact of this 25 percent tariff:

1. Let us assume initially that there is no trade (called autarky) and that only domestic supply and demand determine the equilibrium price $\left(P^{*}\right)$ and quantity $\left(Q^{*}\right)$.

2. Assume the economy is opened to free trade with no tariffs or other trade barriers. This yields a world export price of $\$ 599{ }^{16}$ per gross tons (determined by demand curve, $D$, and the perfectly elastic supply curve $S_{F T}$ ) and the domestic supply, $Q_{S}$, and domestic demand, $Q_{D}$. Since domestic demand, $Q_{D}$, exceeds domestic supply, $Q_{S}$, the difference $\left(Q_{D}\right.$ - $Q_{S}$ ) represents the import of steel into the United States at the world export price of $\$ 599$.

3. Since a 25 percent tariff on steel is equivalent to a 25 percent tax, the supply curve will shift upward from $S_{F T}$ to $S_{W T}$ (supply with tariff) thus raising the price to $\$ 749$. At this price, domestic production increases to $Q^{\prime} S$ and domestic consumption falls to $Q^{\prime} D$, thus the level of imports falls from $Q_{D}-Q_{S}$ to $Q_{D}^{\prime}-Q_{S}^{\prime}$. The rectangular area $B$ represents tariff revenue collected by government (tariff of $\$ 150$ per gross ton multiplied by tons of steel imported into the United States). Triangles $A$ and $C$ together represent the societal (deadweight) loss due to tariffs restricted trade (area $A$ represents a loss

\footnotetext{
15 Every illustrative diagram used in paper is based on Ellenberg's (2001) argument cited in footnote 7.

16 According to SteelBenchmarker: http://steelbenchmarker.com/files/history.pdf, p.14, \$599 was the world export price of steel as of June 11, 2018. This illustration also applies to aluminum and other goods with tariffs.
} 
because the added domestic supply could have been imported at a lower price while area $C$ results from consumer buying less and paying more). More importantly, economists predict that the job losses in industries that use steel and aluminum in the United States will exceed any job gains in steel and aluminum industries.

Generally, Congressional Republicans tout themselves as free trade hawks, but in this instance, they are afraid of endless public humiliation from REP-POTUS if they join Democrats in opposition to his trade isolationism and the destruction of global alliances (e.g. UN, NATO, WTO, and NAFTA). A major aspect not captured in Figure 2 is the retaliatory tariffs by the trading partners of the United States. There is no doubt that this would escalate into trade wars between the United States and its trading partners in different parts of the world, but more importantly, this could be a revisit of the Smoot-Hawley Tariff Act of 1930, which raised tariffs on thousands of goods. The consensus among economists and economic historians is that the passage of the Smoot-Hawley Tariff Act exacerbated the Great Depression [see Tausig (1931)]. Given the ongoing trade wars with our neighbors and trading partners, experts predict that jobs loss could be in the millions in the United States; thus some pundits now tagged this as "Make America 1930 Again."

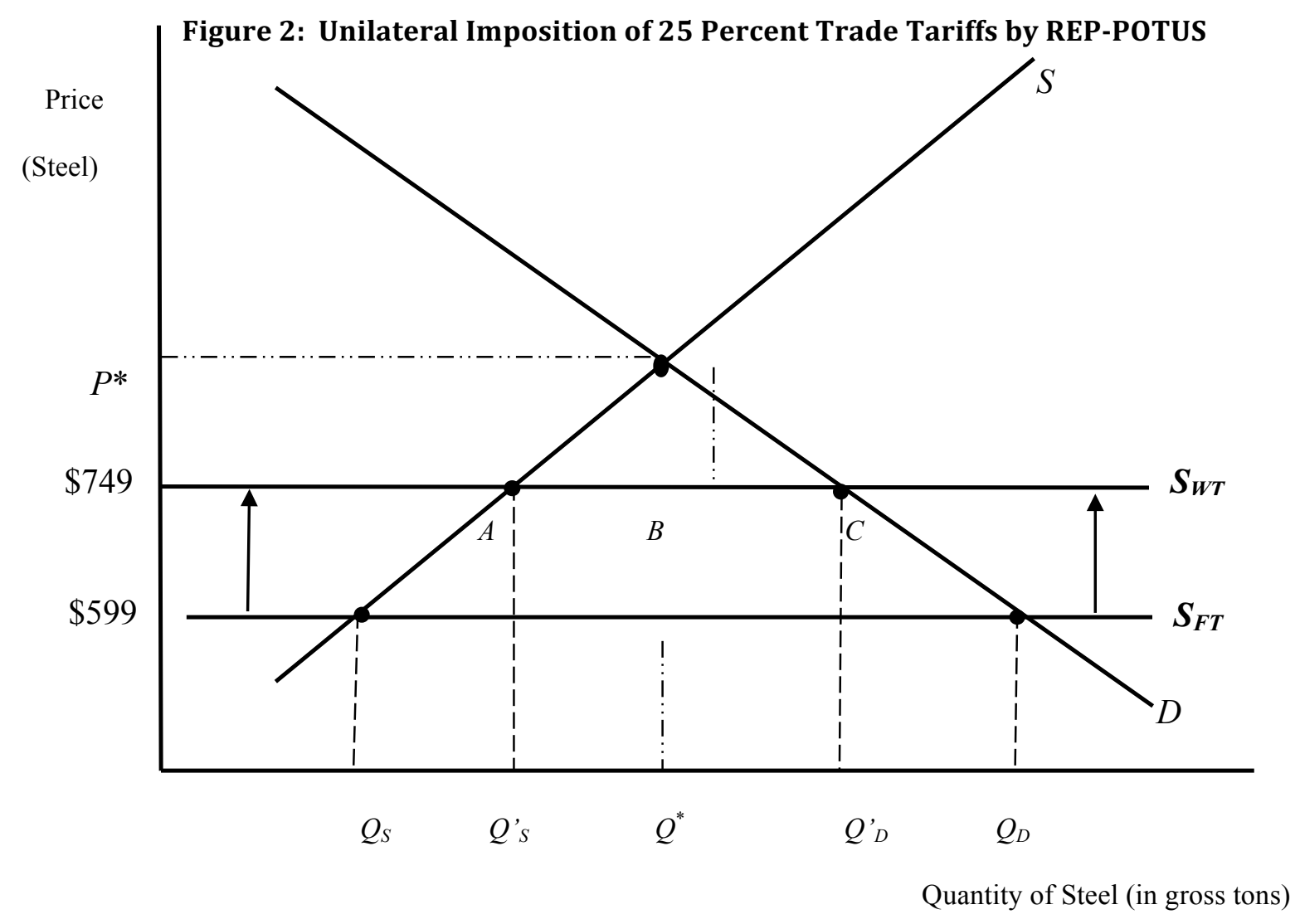

Another area in which partisan polarization could have adverse consequences on different economic institutions is the issue of immigration. For the past three decades, a REP-POTUS or a DEM-POTUS and Congress have failed to pass any meaningful immigration reform since the Immigration Reform and Control Act of 1986, which imposed penalties on employers who knowingly hire illegal aliens. Before then, the penalty for illegal employment was deportation. The House of Representatives passed the Border Protection, Anti-Terrorism, and Illegal Immigration Control Act of 2005, and the Senate passed the Comprehensive Immigration Reform Act of 2006, but neither bill became law because the Conference Committee could not 
resolve the differences in both bills. The argument is that since illegal immigration ${ }^{17}$ became a prominent policy issue in the late 1980s, this also became a strongly divisive issue within and across both parties, and that this has contributed to racial hatred and partisan political polarization since then. Arguably, illegal immigration is particularly polarizing because both parties have opposing views. To some people, especially within the Republican Party, every illegal immigrant deprives a citizen or legal resident of a job; and to others, illegal immigrants perform jobs that no American citizen would do. Some politicians consider illegal immigrants as criminals and/or breeding animals, which is illustrative of the hate-creating stories that hate groups and racist individuals consume. This was the foundation of the unwavering support for Trump's candidacy in 2016 (REP-POTUS) among the core conservative Republican base, just as self-deportation of undocumented workers was one of the major policy positions during Mitt Romney's presidential campaign in 2012.

According to the Department of Homeland Security, there are roughly 12 million illegal immigrants living in the United States. The central question for analysis is: Would the deportation of roughly 12 million illegal immigrants affect the labor market if they self-deport or if the Trump administration deports them? In answering this question, let us assume that the labor market consists of two categories of workers: highly skilled and unskilled, and that these illegal immigrants belong to the category of unskilled workers who cannot replace the highly skilled domestic workers. Simply put, the unskilled illegal immigrant workers complement the highly skilled workers. As depicted in Figure 3, we assume the labor demand and supply for unskilled workers to be highly elastic. ${ }^{18}$

Figure 3: Demand and Supply of Unskilled Workers in the United States

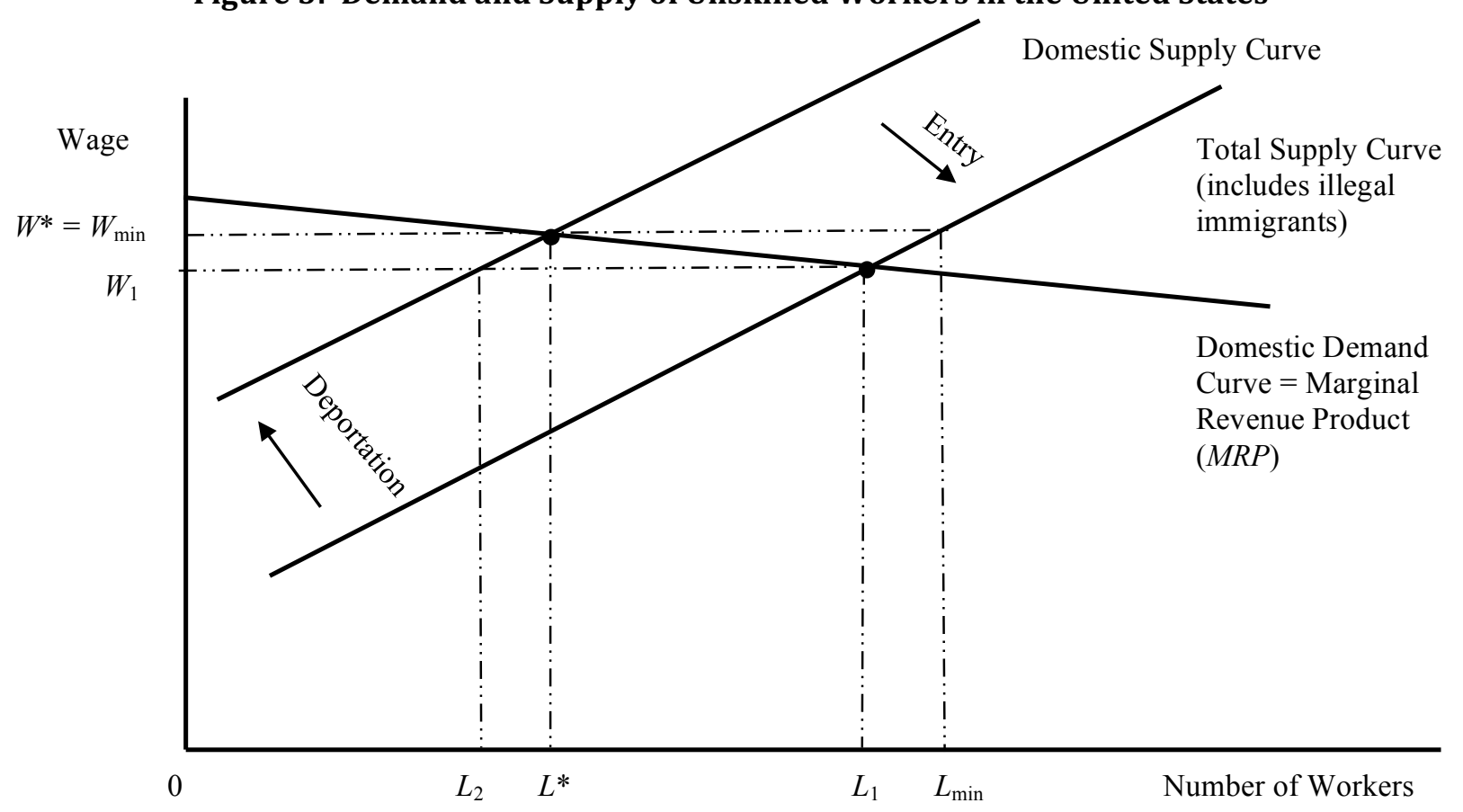

\footnotetext{
17 Illegal immigration falls into two categories. The first category consists of immigrants who enter legally but overstay the provision of their visas; and the second category consists of those immigrants who enter into the United States without a visa through illegal border crossing, use fake documents to get through different ports of entry or being smuggled into the country by using "coyotes."

${ }^{18}$ Labor elasticity, either demand or supply, is defined as the percentage change in quantity of labor divided by the percentage change in the wage rate.
} 
In the absence of illegal immigrants in the labor market for unskilled workers, equilibrium occurs at the intersection of the domestic labor supply and labor demand curves with $W^{*}$ and $L^{*}$ as the equilibrium wage and employment, respectively. The entry or influx of illegal immigrants into the labor market for unskilled workers would shift the labor supply curve to total supply curve, and this would drive down the wage to $W_{1}$ with employment increasing to $L_{1}$. At $W_{1}, L^{*}-L_{2}$ shows the domestic workers who are willing to exit the labor market because they do not want to compete with illegal workers. If $W^{*}$ is equal to the legal minimum wage $\left(W_{\min }\right)$, then the entry of unskilled illegal immigrants increases employment to $L_{\min }$, and $L_{\min }-L^{*}$ workers will complement the $L^{*}$ domestic workers. Whether the wage is $W^{*}=W_{\min }$ or $W_{1}$, the deportation of all illegal immigrants from the labor market for unskilled workers would end up restoring the equilibrium wage and employment back to $W^{*}$ and $L^{*}$, respectively. If we consider that illegal immigrants have links to all other markets and not just the unskilled labor market analyzed in Figure 3, then this suggests that the deportation of roughly 12 million illegal immigrants would have a more pronounced adverse effects in all markets. The backward shifts in the demand and supply curves in other markets would result in a serious economic quagmire, especially in the goods and services markets.

Given the hateful stories peddled about illegal immigrants, this issue will continue to dominate any future political discourse because the ideologically polarized Congress and the highly polarized electorate may find it difficult to agree on any meaningful immigration reform. To summarize the effects of the ongoing trade wars with our trading partners and the unresolved illegal immigration policy on the political economy of the United States so that non-economists can understand, a classic textbook diagram that describes the aggregate economy is presented in Figure 4. Given that the current unemployment rate hovers around four percent, point $A$ depicts the short-run macroeconomic equilibrium where the aggregate demand $(A D)$ curve intersects the short-run aggregate supply (SRAS) curve with aggregate price level at $P_{A}$ and actual real GDP at $Y_{A}$. If the trade wars ${ }^{19}$ continue and illegal immigrants are deported from the United States, both the $A D$ and $S R A S$ curves will shift backward by different magnitudes. As shown in Figure 4, the short-run macroeconomic equilibrium will be at point $B$ where $A D_{1}$ intersects $S R A S_{1}$ with the new price level at $P_{B}$ and real GDP at $Y_{B}$, which is a recessionary real GDP level. In other words, the ongoing tariff wars could force many

\footnotetext{
19 The combination of trade wars and deportation of illegal immigrants will have negative effects on aggregate demand and aggregate supply sides of the economy. The consumption, investment, and net exports components or determinants of $A D$ are adversely affected. It is important to note that some of the roughly 12 million illegal immigrants are entrepreneurs and suppliers of various goods and services; therefore, deportation will have adverse effect on SRAS curve as well. What is impossible to predict, at this point, is the magnitude of these effects on $A D$ and $S R A S$ curves.
} 


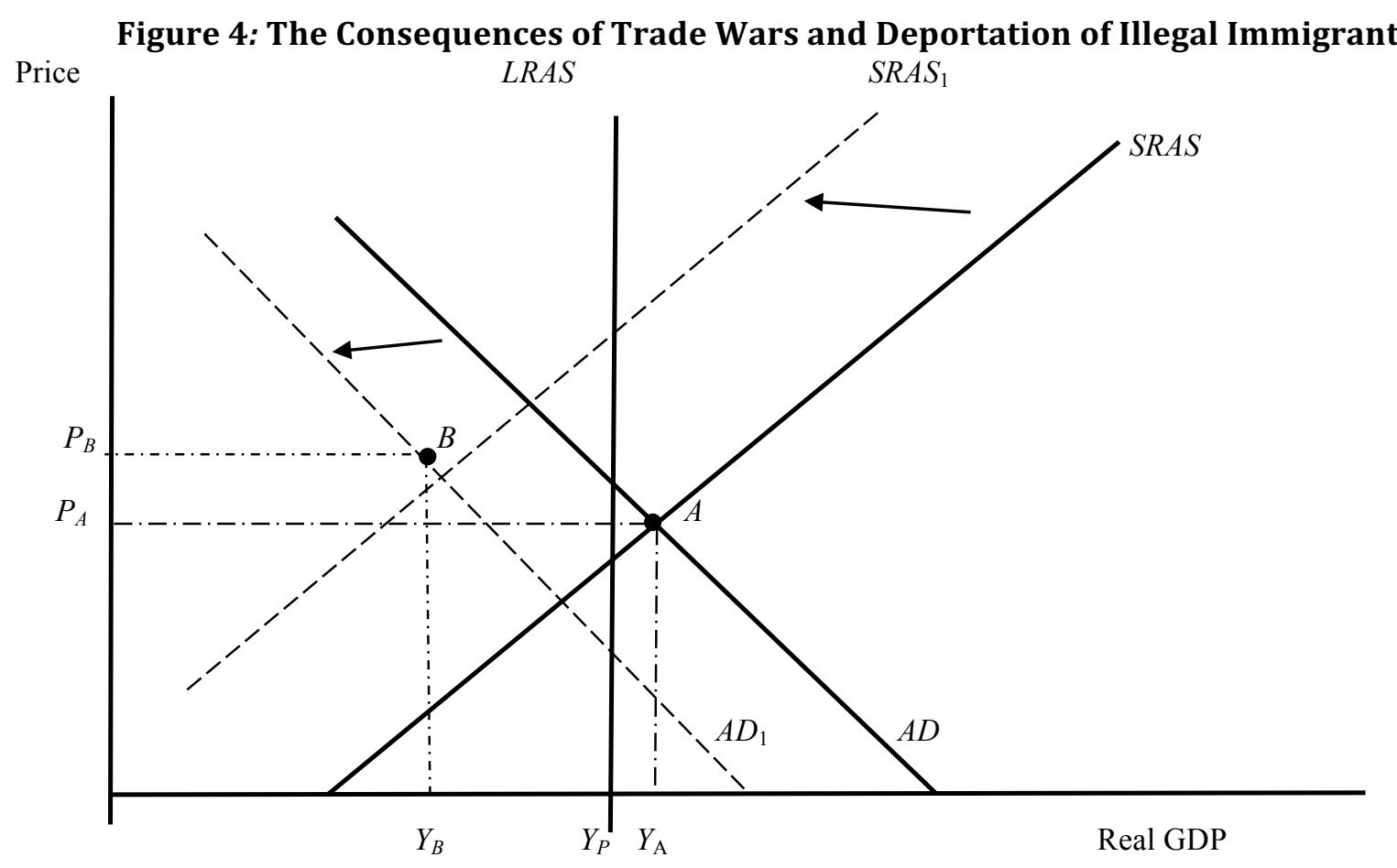

firms to move their production outside the United States; therefore, the expectation of a recessionary real GDP at $Y_{B}$ with $P_{B}$ higher than $P_{A}$, thus the economy would experience a period of stagflation with high unemployment and high inflation rates.

Finally, what experts are hesitant to point out is that complicit partisan polarization has empowered the REP-POTUS to undermine the effectiveness of many other vital economic institutions such as the United States Postal Service (USPS) and the Federal Reserve Bank (FRB). The REP-POTUS engages in interferences and distortions in various markets. For example, the REP-POTUS singled out and criticized the owner of Amazon for the postage contract signed with the USPS. Essentially, he considered Amazon as a "free rider." The Council of Economic Advisers (CEA) should inform the REP-POTUS that over the past two decades, technology via process innovation has undercut USPS's monopoly power with respect to first class mail thus forcing it to compete with FEDEX, UPS, DHL, and other mail delivery services in an oligopoly mail-package market. If Amazon and other companies cancel their postage contracts with the USPS and it goes out of business, there would be millions of jobs loss, which may trigger an economic recession.

Recently, the REP-POTUS questioned the independence of the FRB, which is troubling but not surprising because the current REP-POTUS, as a presidential candidate in 2016, falsely accused and criticized Janet Yellen - the first Chairwoman of the FRB - for not raising the interest rate in order to favor the Obama administration. Now that the FRB, under his own appointed Chairman, plans to use a contractionary monetary policy (raise interest rate) to mitigate the looming inflation, REP-POTUS condemns how the FRB conducts monetary policy. The question is: Can the REP-POTUS undermine the independence of the FRB? Worldwide, Central Banks revere the FRB for its independence in conducting monetary policy. In fact, the Chairperson of the FRB is the second most powerful person in the world and whenever he/she speaks, the financial world listens.

Based on the observed obsequious behavior of Congressional Republicans, pundits should expect them to find their "missing" oversight powers, which they can then use to intimidate and destabilize the FRB and the entire financial system of the United States. In this 
environment of complicit partisan polarization, economists should expect the servile Congressional Republicans to use their subpoena powers to compel the FRB's Chairman or the 7 Board of Governors or the 12 members of the Federal Open Market Committee to testify before the Senate Committees on Finance regarding the rationale for raising the interest rate. Repeated subpoenas combined with the REP-POTUS's open humiliation and false narratives about the role of the FRB as a vital economic institution could force the FRB to concede to the whims of the REP-POTUS. If the REP-POTUS and Congressional Republicans succeed in undermining FRB's independence, this would usher in an era of a "Republican Business Cycle (RBC)" made in Washington, and the National Bureau of Economic Research's Business Cycle Dating Committee may not be able to determine the dates of turning points of RBC. This paper asserts that the unchecked REP-POTUS's interferences in vital economic institutions are possible due to the pervasive partisan polarization because the extremely polarized Congress can no longer provide the oversights required to check the REP-POTUS's excessive overreach. Before we experience episodes of RBC, the CEA should enlighten the REP-POTUS about the relationship between money supply and inflation rate; and that in countries where the governments control their Central Banks, they experience hyperinflation rates.

\section{The Effects of Hatred and Partisan Polarization on Political Institutions}

One of the most important political institutions is the government, which is responsible for providing a strong legal environment under which the rule of law, enforcement of contracts and property rights, and representative democracy thrive. Our government with its two political parties establishes and monitors domestic relations and global alliances [United Nations (UN), World Trade Organization $\left(\mathrm{WTO}^{20}\right.$ ), North Atlantic Treaty Organization (NATO), North American Free-Trade Association (NAFTA), Paris Climate Accord (PCA), and TransPacific Partnership (TPP)] with other countries. In addition, the government provides an independent judicial system where no one is above the rule of law, and the professional nonpartisan law enforcement agencies enforce the rule of law. In the current political environment in which overt racial-gender hatred and complicit partisan polarization are complementary, the current REP-POTUS constantly peddles false narratives in order to undermine the credibility of the judicial system, intelligence and law enforcement agencies. Given the absence of Congressional oversights, nonpartisan legal pundits agree that the REPPOTUS's systematic abuse of the rule law either through the violation of the emoluments clause or the nepotism clause, delegitimizing the judicial system, and discrediting the intelligence communities are strategic moves to circumvent the Constitution, undermine representative democracy, and ultimately establish autocracy. The consensus among legal and political experts is that Republicans are explicitly and implicitly complicit in the bullying strategic maneuvers by the REP-POTUS because they want total control of all the branches of government.

The Watergate scandal of the early 1970s was an illustration of last minute bipartisanship when the rule of law was under serious attack by another REP-POTUS and Republicans, in the end, refused to abrogate their Constitutional duty of checks and balances. According to political historians, President Nixon resigned before any impeachment hearings were brought to the floor of the House of Representatives because some patriotic Republicans rose to inform him not to expect their support if impeached. Today, we see the tacit complicity to undermine the rule of law. Research studies have argued that the social issues of the 1960s and 1970s drove Democrats and Republicans to their ideological corners and thus Congress became increasing dysfunctional due to the politics of hatred and partisan polarization. The issues that were

${ }^{20}$ Formerly known as the General Agreement on Tariffs and Trade (GATT) originally signed by 23 founding countries. 
previously resolved through compromises and coalitions between both parties became increasingly difficult such that shutdowns of government became the avenue for Congressional legislative solutions.

In this era of growing racial-gender hatred and partisan polarization within and across parties, political pundits argue that Congressional Democrats and Republicans no longer provide the checks and balances whenever they control the government. This implies that partisan polarization has emboldened the current REP-POTUS to reveal his racial-gender hatred and peddle hate-creating stories and repeated false narratives about the other groups in his attempt to undermine the rule of law, the credibility of the judicial system, and intelligence communities. Evidently, the "Right-wing" ${ }^{21}$ Republicans prefer an authoritarian REP-POTUS because their control of Congress and the White House matters more than upholding the Constitution and democratic norms.

Another important question is: Could overt racial-gender hatred and partisan polarization, which emboldened the current REP-POTUS to circumvent and undermine all Constitutional norms and representative democracy in the United States lead to global-hatred, division, and the destruction of global alliances? Obviously, this is a tough question to answer at this point because we are less than halfway into the REP-POTUS's presidency, and no one knows how long the Republican Party would have control of both chambers of Congress. On the one hand, if the current trend continues and Republicans maintain control of the executive and legislative branches of government after the next mid-term and presidential election cycles with the current REP-POTUS, one should expect a continuation on the current path of repeated hatredcreating stories and the delegitimization of the intelligence and law enforcement agencies through endless false accusations. In addition, one should expect Congressional Republicans to use subpoena powers to intimidate. It should come as no surprise if moderate and conservative Republicans embrace the monarchial tendencies of the current REP-POTUS because they are afraid of public humiliation, which he has adeptly dished out to those who disagreed with him. Gradually, a majority of the electorate along with the conservative Republicans will continue to believe and consume the hate-creating stories and false narratives that the current REP-POTUS peddles until representative democracy transitions into autocracy.

By 2020 or 2024, the enormous damage to representative democracy in the United States may be so profound that it may force voters to rethink and reconsider the "Electoral College" democratic system that yielded two REP-POTUSs in less than two decades. In the current political environment of growing racial-gender hatred and extreme partisan polarization, one wonders how receptive the general electorate, especially the Republican voters, would be if a DEM-POTUS wins the 2020 and/or 2024 presidential elections by merely two Electoral College $^{22}$ votes (270-268) in each case but loses the popular votes each time by six to seven million votes. In hindsight, what would Republican voters and Congressional Republicans think about the Electoral College system if their presidential candidates had won the 2000 and 2016 popular votes by four to six million votes but lost the Electoral College votes by a margin of two in both cases? Would the Republicans have condoned a DEM-POTUS who egregiously violated

\footnotetext{
${ }^{21}$ According to Glaeser (2005, p. 72), "Right-wing figures, like Bismarck and Metternich, fought not against income redistribution, but against constitutions and democracy.

22The historical record shows that five REP-POTUSs lost the popular votes but won through the Electoral College votes. John Quincy Adams was the first in this category of presidential winners, and when he won in 1824, he was then of the Democratic-Republican Party from 1808 to 1830 and then the National Republican Party from 1830 to1838.
} 
the emoluments clause by not divesting completely from his/her business interests while in office or the Federal Anti-Nepotism Statute by making relatives Senior Advisors in the Oval Office? Pundits avoid these challenging questions.

Conjecturally, the current REP-POTUS could be a signal of the dictatorial one-party state that Republicans wanted all along, and at last, they found one of the exceptional "entrepreneurs of hate" ${ }^{23}$ who is an adept manufacturer, repeated propagator, and peddler of false narratives to guide them along the path to undermine the Constitutional norms and the rule of law. This could explain why Congressional Republicans did not allow President Obama to fill many judicial vacancies during his tenure, especially the Supreme Court vacancy that occurred in February of 2016. If Democrats managed to gain control of either the House or Senate or both in 2018 elections with a REP-POTUS in the White House, we may return to a two-party system with the proper interpretation of the Constitution, the rule of law, and government accountability. What is not predictable is the future political environment as to whether Democrats would be complicit with a DEM-POTUS, in retaliatory act to what political pundits perceive as Republicans' obsequiousness, if Democrats control of the executive and legislative branches of government in 2020 and/or 2024 and the DEM-POTUS decides to use the playbook of the current REP-POTUS. If the next DEM-POTUS shows autocratic propensities and Democrats are complicit, just as the Republicans are with their REP-POTUS, this may lead to "Make America a Monarchy Again."

An important aspect of the question under analysis is whether the growing overt hatred and partisan polarization in the United States could have global implications. Pundits in international affairs see the current REP-POTUS as replicating his domestic playbook of hatecreating false narratives and racial denigrations at the world stage by his repeated denigrations of leaders of other countries such as Australia, Britain, Canada, France, Germany, and Mexico. The repeated denigrations also extend to all relevant global alliances such as the United Nations, NATO, WTO, NAFTA, PCA, TPP, and the Group of Seven (G7) Summit, which relied on the leadership of the United States since the end of World War II. Political experts consider the "America First" foreign policy as the "US versus other countries" in these alliances, and that the aim is to portray these countries as the "free riders" that are globally delinquent in their obligations. The intention of the repeated denigrations of these alliances is to make the United States a country that hates other countries for committing global crimes and portray these countries as "free riders." In retaliation, these countries ${ }^{24}$ will hate the United States for the REP-POTUS's endless denigrations, thus creating a contagious global-hatred. The "America First" foreign policy stance will foster global-hatred and polarization within these global alliances thus alienating the United States, which will cause the abdication of its leadership role in the global political economy.

\section{The Effects of Hatred and Partisan Polarization on Social Institutions}

As pointed earlier, economic, political, and social institutions are interdependent in a representative democracy. Sociologists would argue that social institutions encapsulate the other institutions we discussed in the previous sections. One can view social institutions from different prisms: family by way of marriage, education through the various school systems, and religion through different churches where people worship. In addition, it is important to point out that economic, political, and social institutions cannot survive in the absence of trust, which is essential in building social capital. According to Weil (2013), economists and sociologists

\footnotetext{
23 See Glaeser (2005).

${ }^{24}$ According to the Pew Research Center, June 26, 2017, many countries do not have confidence in the REPPOTUS.
} 
consider social capital to be the "value of social networks that people have and of the inclination of people in those networks to do things for each other. In a society where people have large circles of acquaintance, and where people who know one another are inclined to be helpful, social capital is high. In a society where people are isolated socially, or where there is no norm of helping out those one knows, social capital is low. Social capital is the glue that holds society together."

The question is: What are the effects of racial-gender hatred and partisan polarization on the core - family, education, religion, ${ }^{25}$ trust, mass and social media or free press, and social capital - of social institutions? Family building through marriage is an important societal norm; and the issue not often discussed is the survival of modern marriages involving liberal or moderate Democrats and conservative Republicans in this era of racial-gender hatred and extreme partisan polarization. Based on societal observations and the current norms in the United States, one can argue that racial-gender hatred and partisan polarization threaten family unity, thus promoting marriage and religious segregations based on political ideology and deeprooted mistrust between both parties.

As discussed in the background section, the changes in the mass media environment of politics since the Watergate scandal and the advent of cable news networks and social media have also contributed to racial-gender hatred and partisan polarization. Even though it is impossible to test the relationship because of the absence of data on media environment, but one can implicitly interpret the unidirectional causality running from mass media environment to racial-gender hatred and partisan polarization. In today's digital world, one cannot underestimate the importance of the mass-social media environment not only in building social capital across difference groups, but also in its providing the path to operationalize the five basic liberties guaranteed by the First Amendment. Given today's political landscape, the racial-gender hatred and partisan polarization have emboldened the REP-POTUS in attacking and undermining the basic liberties.

It is a common knowledge that the REP-POTUS is relentless in his attacks on the free press and the portrayal of the free press as the "enemy of the people." What society and political pundits underestimate is that these strategically persistent attacks are designed and intended to delegitimize and destroy the free press or mass media with the hope of creating a "conservative national news network," which exists in many autocratic democracies and/or dictatorships. In other words, the REP-POTUS engages in "mass media scathing" ${ }^{26}$ because the conservative Republican base, hate groups, and racist-individuals easily consume his false narratives. Based on the enormity of partisan polarization in the United States, REP-POTUS has managed to convince the Republican base, hate groups, and racist-individuals to see the free press or mainstream media as the nefarious organization that must be destroyed. Comparing the mass media environment of the past 17 years of the $21^{\text {st }}$ century to the last two decades of the $20^{\text {th }}$ century, the main contention is that society is embroiled in mass media segregation

\footnotetext{
25In early and late 1990s, the Republican evangelical-moral majority denounced President Clinton (DEM-POTUS) for his sexual infidelity and impropriety on religious grounds. Two decades later, the same evangelical-moral majority Republican support President Trump's infidelity by essentially arguing that they did not vote for a "messiah." Political pundits consider this is as the highest form of religious hypocrisy manifested and/or obscured by partisan polarization.

26 The REP-POTUS condemns certain mass media outlets: newspapers and cable news outlets, but favors those that could potentially be the national news network if successful in undermining the process and everything enshrined in the First Amendment.
} 
based on deep-rooted political ideologies as epitomized by the renewed overt racial-gender hatred by hate groups or racist-individuals and radical partisan polarization.

Before the establishment of the Cable News Network (CNN) in 1980, voters got the daily news, with no specific preference, from $\mathrm{ABC}, \mathrm{CBS}, \mathrm{NBC}$, and the local or national newspapers. In contrast, in today's media environment, voters consume their daily news from cable news outlets that represent their liberal or conservative political ideologies. These news and social media outlets now become the supply channels of hate-creating false narratives about other groups and other countries who are staunch allies of the United States. In addition, the growing media division based on political ideologies is also reflected in the behaviors of Congressional members, especially the current REP-POTUS and Republicans, who only engage in assortative matching with respect to their daily or weekly appearances in ideological-specific media news/cable outlets.

The relevant issue that pundits must consider is society's reaction if hate groups and angry racist-individuals begin violent attacks on reporters based on the false narratives peddled by the REP-POTUS and some Republicans that the reporters are the "enemy of the people." The attempts to destroy the free press or speech (the bedrock of social institutions) raise several challenging questions that pundits must consider. What happens if many in our society condone hate groups and reporters suddenly begin to disappear for doing their jobs as enshrined in the Constitution? What happens if the current REP-POTUS silences the free press/speech and revokes the licenses of ABC, CBS, NBC, CNN, and MSNBC? If the REP-POTUS succeeds in undermining the economic, political and social institutions of the United States, what message does this convey to the rest of the world? Can a representative democracy survive if the electorate is highly polarized? These are challenging questions for pundits to answer because no one expects that the $115^{\text {th }}$ Congress would display obsequiousness when a REP-POTUS exhibits wanton abuse of executive powers. More importantly, these questions are difficult to answer because they are not quantifiable for statistical analysis.

\section{METHODOLOGY AND ESTIMATED RESULTS}

Despite the challenging questions that research scholars and pundits face in this era of increasing racial-gender hatred and partisan polarization, the first objective in this section is to test whether the hate crime laws were effective in reducing hate crimes as shown by the model depicted in Figure 1. To do this, I examine the trends in annual hate crimes before and after the passage of the Hate Crime Prevention Act (HCPA) in 2009. Based on this observation, I test the null hypothesis $\left(H_{0}\right)$ that the annual average hate crimes (AAHCs) before the passage of the HCPA in 2009 are less than or equal to AAHCs after the passage of the HCPA in 2009. The research hypothesis $\left(H_{R}\right)$ is that $\left.A A H C\right|_{\text {Before-HCPA }}$ is greater than $\left.A A H C\right|_{A f t e r-H C P A}$. That is:

$$
H_{0}:\left.A A H C S\right|_{\text {Before- } H C P A} \leq\left. A A H C s\right|_{\text {After-HCPA }} \text { vs } H_{\mathrm{R}}:\left.A A H C s\right|_{\text {Before-HCPA }}>\left.A A H C s\right|_{A f t e r-H C P A}
$$

As Fischer (2016), Dreid and Najmabadi (2016), Quintana (2017), Kerr (2018), and Bauman (2018) argued, an important challenge is the increase in anti-Semitic vandalism and whitesupremacist propaganda at colleges and universities. According to Bauman (2018), the Department of Education recorded a 25.5 percent increase in hate crimes between 2015 and 2016 across 775 colleges and universities in the United States. At this rate, hate crimes at colleges would double before 2020 .

With the hate groups emboldened to target colleges and universities as the recruiting centers and hate crimes could double in two years, the question for empirical analysis is whether this raises any alarm in terms of the long-run consequences. If these hate groups succeed in their 
recruitment of students, this may have multiplier effects for many generations to come, not only at colleges and at universities nationwide, but also the global contagion effect. For these hate groups, their main objective is to indoctrinate and spread their vile hate ideologies for students to acquire along with their acquisitions of human capital. To shed more light on this concern, the second objective is to test the null hypothesis $\left(H_{0}\right)$ that the mean hate crimes (MHCs) at colleges and universities in 2015 are greater than the MHCs in 2016 and vice versa for the research hypothesis $\left(H_{R}\right)$. That is:

$$
H_{0}:\left.M H C S\right|_{2015}>\left.M H C S\right|_{2016} \text { vs } H_{R}:\left.M H C s\right|_{2015}<\left.M H C s\right|_{2016}
$$

Society should not be concerned if we confirm $H_{0}$ because it implies that $M H C s$ across colleges and universities are declining. However, society should be concerned if we confirm $H_{R}$ because of the multiplier effects from the successful recruitments of students into these hatred ideologies.

Furthermore, the game theoretic framework highlights that Congress and any POTUS can achieve high Congressional legislative productivity (CLP) in a strong bipartisan environment where $\alpha=\lambda=1$ or low CLP in an extremely partisan polarized environment where $\alpha=1$ and $\lambda=$ 0 or $\alpha=0$ and $\lambda=1$ and the laws are enacted only through partisan majority. I consider CLP as the necessary political investment in the rule of law required to sustain representative democracy and an effectively functioning political economy. Therefore, the third and final objective of this section based on the discussions in the previous sections is to provide the appropriate econometric method through which to evaluate whether partisan polarization and government shutdowns (GSD) have statistically significant effects on $C L P$. The relationship is expressed in linear regression form as:

$$
C L P_{t}=\Phi_{0}+\Phi_{1} P C I_{t}+\Phi_{2} G S D_{t}+\xi_{t}
$$

where $P C I_{t}$ is the measure of partisan conflict index developed by the Federal Reserve Bank of Philadelphia, $G S D_{t}$ is a dummy variable for government shutdowns, and $\xi_{t}$ is the random error term. Based on the discussions in the previous sections, I expect the coefficients of $P_{C I}{ }_{t}^{27}$ and $G S D_{t}$ to have negative effects on $C L P_{t}$ (that is, $\Phi_{1}<0$ and $\Phi_{2}<0$ ).

Tables 3, 4, and 5 report the estimated results for equations (3), (4), and (5), respectively. In Table 3, the estimated $t$-statistics of 8.02 at the marginal significance level of $\alpha=0.01$ is greater than the table value, thus I reject $H_{0}$ in favor of $H_{R}$. This confirms that hate crime laws, especially the passage of HCPA of 2009 under President Obama, contributed to the statistically significant reduction in hate crimes between 2009 and 2016. The $-1,854.1$ reported in Table 3 shows the annual average difference or reduction in hate crimes during the Obama administration if compared to two previous administrations. During the 2015-2016 presidential election, hate crimes increased by 4.6 percent, which

\footnotetext{
27 Many studies have used varieties of NOMINATE (D, W, and DW) scores, based on roll call votes, as the proxies to measure Congressional polarization. I use the PCI developed by the Federal Reserve Bank of Philadelphia because it is a more comprehensive measure of partisan polarization or conflict than these NOMINATE measures. For more on the use of PCI data, see Azzimonti $(2014,2018)$ and www.philadelphiafed.org/research-and-data.
} 
Table 3: Test of $H_{0}:\left.A H C s\right|_{\text {pre-HCPA }} \leq\left. A H C s\right|_{\text {post-HCPA }} V s H_{R}:\left.A H C s\right|_{\text {pre-HCPA }}>\left.A H C s\right|_{\text {post-HCPA }}$

\begin{tabular}{|c|c|c|c|c|c|c|c|}
\hline \multicolumn{4}{|c|}{ Annual Hate Crimes Pre-HCPA } & \multicolumn{4}{|c|}{ Annual Hate Crimes Post-HCPA } \\
\hline $\mathrm{N}_{\text {pre-HCPA }}$ & AHCs pre-HCPA & $s_{\text {pre } H C P A}^{2}$ & Spre-HCPA & $\mathrm{N}_{\text {post-HCPA }}$ & AHCs post-HCPA & $s_{\text {post } H C P A}^{2}$ & Spost-HCPA \\
\hline 13 & $7,932.6$ & $402,446.7$ & 634.4 & 8 & $6,078.5$ & $139,321.00$ & 373.3 \\
\hline
\end{tabular}

pundits attributed to the current REP-POTUS's open display of racism and racial-gender hatred during his candidacy.

In Table 4, the estimated $t$-statistics of 3.104 at the marginal significance level of $\alpha=0.01$ is greater than the table value, thus I reject $H_{0}$ in favor of $H_{R}$. This statistical significance confirms the data evidence provided by Bauman (2018), which showed that hate crimes in 775 colleges and universities increased by 25.5 percent in 2016. This is consistent with the FBI data, which showed that 10 hate crimes, which occurred on November 8, 2016 quickly increased to 27 hate crimes on November 9, 2016, which implied 170 percent increase in hate crimes within 24 hours. Given the data evidence and the current political trend, this paper affirms that the increase in hate crimes at colleges and universities in the United States will continue into the near future because students are the "targeted consumers" of the hate-creating

Table 4: Test of $H_{0}:\left.M H C\right|_{2015}>\left.M H C\right|_{2016}$ Vs $H_{R}:\left.M H C\right|_{2015}<\left.M H C\right|_{2016}$

\begin{tabular}{ccccc|cccccc}
\hline \multicolumn{4}{c|}{ Hate Crimes at Colleges and Universities in 2015 } & \multicolumn{5}{c}{ Hate Crimes at Colleges and Universities in 2016 } \\
\hline HCs & $\mathrm{N}_{2015}$ & MHCs $_{2015}$ & $S_{m h c \mid 2015}^{2}$ & $\mathrm{~S}_{\mathrm{mhc} \mid 2015}$ & 1,036 & $\mathrm{HCs}$ & $\mathrm{N}_{2016}$ & $\mathrm{MHCs}_{2016}$ & $S_{m h c \mid 2106}^{2}$ & $\mathrm{~S}_{\mathrm{mhc} \mid 2016}$ \\
775 & 1.34 & 3.55 & 1.88 & & & 1,300 & 775 & 1.68 & 5.79 & 2.41 \\
\hline \multicolumn{4}{c}{ Difference in MHCs $=0.34$, t-statistics $=3.104^{*}$, and ${ }^{*}=$ significant at $\alpha=0.01$} \\
\hline
\end{tabular}

stories and false narratives supplied by some politicians and the current REP-POTUS. In essence, society should be concerned because these hate groups will succeed in the recruitment of some college students into different racial-gender hate groups based on political ideologies with long-run impact being the intergenerational transfer of racial-gender hatred by those students newly schooled in these vile ideologies.

Table 5 provides the estimated results for equation (5). As predicted, the coefficients of $P C I_{t}$ and $G S D_{t}$ are negative and statistically significant at the marginal significance level of $\alpha=0.01$. These results also confirm the high negative correlation that exists between $C L P_{t}$ and $P C I_{t}, C L P_{t}$ and $G S D_{t}$, and $P C I_{t}$ and $G S D_{t}$ not reported here in order to conserve on space. The negative finding is consistent with Azzimonti's (2018) study, which found a "negative relationship between the $\mathrm{PCI}_{t}$ and aggregate investment as well capital investment rates at the firm level in the United States, and that these declines are persistent, which may help explain the slow recovery observed since the 2007recession ended."

Table 5: Congressional Productivity, Partisan Polarization, and Government Shutdowns

\begin{tabular}{ccccc}
\hline Variables & Coefficients & Standard error & t-statistics & $P$-value \\
\hline Intercept & 914.11 & 88.96 & 10.28 & $0.0000^{*}$ \\
$P C I_{t}$ & -3.07 & 0.73 & -4.22 & $0.0005^{*}$ \\
$G S D_{t}$ & -139.21 & 52.33 & -2.66 & $0.0149^{*}$ \\
\hline
\end{tabular}

$R^{2}=0.58$, Adjusted $R^{2}=0.53$, and * indicates statistical significance at $\alpha=0.01$ or better.

More importantly, Table 5 shows that government shutdowns have statistically significant negative effect on Congressional legislative productivity, and interpretatively, for each government shutdown, Congress sacrifices 139 laws that it could have enacted. 


\section{CONCLUSIONS AND POLITICAL IMPLICATIONS}

This paper analyzes the political economy of the United States in the era of increasing racialgender hatred and extreme partisan polarization. In doing so, the paper uses the concept of revealed preferences of hate groups using the iso-hatred curve analysis and statistical test of mean difference to show that racial-gender hatred by hate groups is on the rise nationally and across college and university campuses because they are emboldened by the current toxic political environment of partisan polarization. Statistical tests confirm the research hypotheses of increasing hate crimes at the national level and across college and universities campuses since the election of 2016. In addition to using the hatred revealed preference analysis, the game theoretic framework highlights the retaliatory behaviors of Congressional Democrats and Republicans based on their deep-rooted partisan ideologies. Evidently, the passages of the Patient Protection and Affordable Care Act of 2010 under a DEM-POTUS and the Tax Cuts and Job Act of 2017 under the current REP-POTUS with strictly partisan support lend strong credence to the tit-for-tat outcomes illustrated in cells II and III in Table 1. Using a linear regression method to evaluate the effects of partisan polarization and government shutdowns on Congressional legislative productivity, the estimated results showed that partisan polarization and government shutdowns have statistically significant negative effects on Congressional legislative productivity in the United States.

With the ongoing tariff-restricted trade wars between the United States and our trading partners, "zero tolerance" immigration policy, entry ban, and the denigration of leaders as well as global alliances, pundits predict that these policies would have adverse effects on the political economy of the United States. Experts on free trade predict that job losses, in those industries that use steel and aluminum, will exceed any job gains in the steel and aluminum industries; and that the Unites States may be on the precipice of the Smoot-Hawley Tariff Act of 1930, which exacerbated the Great Depression. The "zero tolerance," entry ban, and the endless denigrations of alliances may push many countries to develop hatred for the United States, thus looms an era of global hatred.

As for the political implications of racial-gender hatred and partisan polarization, one cannot underestimate that the REP-POTUS has continued his strategically implicit endorsement of racial-gender hatred under the umbrella of partisan polarization in order to undermine the three basic institutions and gradually chip away at representative democracy in the United States. This is a signal to leaders in other countries to emulate the United States. It is debatable and a challenge for future research as to whether an environment of partisan polarization and tribal-racial politics can undermine representative democracy in the United States if any POTUS displays autocratic propensities and his or her party is complicit in circumventing the rule of law and democratic norms. The rationale for their complicity can be attributed to their desire to control of the executive, legislative, and judicial branches of government. Arguably, representative democracy can only survive in a bipartisan political environment where the economic, political, and social institutions can function effectively without interferences and where the majority party is not complicit in the monarchial-autocratic propensities of its leader in the White House.

Furthermore, international pundits consider the "America First" foreign policy of the United States to be not only naïve and isolationist, but also a strategic way to spread the racist- 
supremacists nationalistic ideologies to other western countries. ${ }^{28}$ In addition, the REPPOTUS's intimidation and persistent denigrations of leaders of other countries as well as the entire African continent and allies in different global alliances will lead to international turmoil, global hatred contagion, and polarized global alliances. According to the Pew Research Center, many longtime European allies are losing confidence in the United States' leadership roles in various global alliances under the current REP-POTUS; and this will diminish the United States' leadership roles in the global political economy, especially with respect to the global alliances like NATO.

Overall, one can surmise that as the United States experiences a political environment of increasing open racial-gender hatred and toxic partisan polarization, the three institutional pillars - economic, political, and social - of representative democracy would be weakened, just as those in poor developing countries, if Republicans or Democrats are obsequiously complicit in the autocratic-dictatorial propensities of their REP-POTUS or DEM-POTUS, respectively. In the past two years, the world has witnessed the reversals of Constitutional and democratic norms in the political economy of the United States and the unraveling of global alliances under a REP-POTUS. Essentially, the current REP-POTUS continues to signal to the leaders of other countries that strategic repetitions of hate-creating stories and false narratives are the most effective tools with which to undermine the strong economic, political, and social institutions in any country. In this era of globalization and rapid spread of the news through social media, if the ethnonationalistic ideologies succeed in the United States due to hatred, palpable ramped up anger among the electorate, and partisan polarization, this may have a worldwide contagion effect and a complete breakdown of world order since World War II. Skeptics, who may consider these inferences as too extreme because they think representative democracy is infallibly sacrosanct in the United States, need to research and revisit the history of what happened to the first and other representative democracies in the western world.

\section{ACKNOWLEDGEMENT}

The views expressed in this paper are purely the views of the author and not those of the Connecticut State University-American Association of University Professors (CSU-AAUP) Research Grant who funded this research or Western Connecticut State University. The author gratefully acknowledges Professor Steve Skinner for helpful comments and suggestions.

\section{References}

Abramowitz, Alan I. (2010). The Disappearing Center: Engaged Citizens, Polarization, and American Democracy. New Haven, CT: Yale University Press.

Aldrich, John. (1995). Why Parties? The Origin and Transformation of Political Parties in America. University of Chicago Press.

Ansolabehere, Stephen, John M. de Figueiredo, and James M. Snyder. (2003). "Why is There so Little Money in U.S. Politics?" Journal of Economic Perspectives, 17(1): 105-130.

Ansolabehere, Stephen, Jonathan Rodden, and James M. Snyder. 2006. "Purple America." Journal of Economic Perspectives 20(2): 97-118.

Azzimonti, Marina. (2014). "Partisan Conflict” Working Paper No. 14-19, Research Department, Federal Reserve Bank of Philadelphia, 1-39. www.philadelphiafed.org/research-and-data.

Azzimonti, Marina. (2018). "Partisan Conflict and Private Investment.” Journal of Monetary Economics 93(1): 114131.

28 The objective of "America First" is to deconstruct the "administrative state" and globalization and to signal to other ethnonationalist racists, especially the European countries, to promote the same ethnonationalistic ideologies under similar label - e.g. "Britain First," "France First," “Germany First," and so on. 
Bafumi, Joseph, and Michael C. Herron. (2010). "Leapfrog Representation and Extremism: A Study of American Voters and Their Members in Congress." American Political Science Review 104(03): 519-542.

Bauman, Dan (2018), "After 2016 Election, Campus Hate Crimes Seemed to Jump: Here's What the Data Tell Us," The Chronicle of Higher Education, February 16, 2018, 1-10.

Barber, Michael and Nolan McCarty. (2013). “Causes and Consequences of Polarization.” In Negotiating Agreement in Politics, eds. Jane Mansbridge and Cathie Jo Martin. America Political Science Association

Barber, Michael. (2016). "Ideological Donors, Contribution Limits, and the Polarization American Legislatures" Journal of Politics, 78(1): 296-310.

Baron, David P. (1994). "Electoral Competition with Informed and Uniformed Voters." American Political Science Review 88(1): 33-47.

Bartels, Larry. (2000). "Partisanship and Voting Behavior 1952-1996.” American Journal of Political Science 44(1): 35-50.

Bartels, Larry. (2008). Unequal Democracy: The Political Economy of the New Gilded Age. Princeton, NJ: Princeton University Press.

Bishop, Bill. (2009). The Big Sort: Why the Clustering of Like-Minded Americans Is Tearing Us Apart. New York: Mariner Books.

Bonica, Adam. (2013). "Ideology and Interests in the Political Marketplace." American Journal of Political Science 57(2): 294-311.

Bonica, Adam, Nolan McCarthy, Keith T. Poole, and Howard Rosenthal. (2013). "Why Hasn't Democracy Slowed Rising Inequality." Journal of Economic Perspectives 27(3): 103-124.

Brewer, Mark, Mack Mariani, and Jeffrey M. Stonecash. (2002). Diverging Parties: Social Change, Realignment, and Party Polarization. Boulder, CO: Westview Press.

Bullock, Will, and Joshua D. Clinton. (2011). "More a Molehill than a Mountain: The Effects of the Blanket Primary on Elected Officials' Behavior from California." Journal of Politics 73(3): 915-930.

Carsey, T. M., \& Layman, G. C. (2006). “Changing Sides or Changing Minds? Party Identification and Policy Preferences in the American Electorate," American Journal of Political Science, 50(2): 464-477.

Carson, Jamie L., Michael H. Crespin, Charles J. Finocchiaro, and David W. Rohde. (2007). "Redistricting and Party Polarization in the US House of Representatives." American Politics Research 35(6): 878 -904.

Clinton, Joshua D. (2006). "Representation in Congress: Constituents and Roll Calls in the 106th House." Journal of Politics 68(2): 397-409.

Cooper, Michael. (2012). "Conservatives Sowed Idea of Health Care Mandate, Only to Spurn it

Later." The New York Times. February 14, 2018. http://www.nytimes.com.

Cox, Gary, and Mathew McCubbins. (2005). Setting the Agenda: Responsible Party Government in the U.S. House of Representatives. Cambridge University Press.

DellaVigna, Stefano, and Ethan Kaplan. (2007). "The Fox News Effect: Media Bias and Voting." Quarterly Journal of Economics 122(3): 1187-1234.

Dreid, Nadia, and Shannon Najmabadi. (2016). “Here's a Rundown of the Latest Campus-Climate Incidents Since Trump Election," The Chronicle of Higher Education, December 13, 2016.

Edwards, Mickey. (2012). The Parties Versus the People: How to Turn Republicans and Democrats into Americans. Yale University Press.

Eilperin, Juliet. (2007). Fight Club Politics: How Partisanship Is Poisoning the House of Representatives. Lanham, MD: Rowman \& Littlefield.

Ellenberg, Jordan. (2001). “Growing Apart: The Mathematical Evidence for Congress' Growing Polarization” at www.slate.com/articles/life/do_the_math/2001/12/growing_apart.html. Accessed on May 31, 2018

Ensley, Michael J. (2009). “Individual Campaign Contributions and Candidate Ideology," Public Choice 138(1): 221-238.

Federal Bureau of Investigation. (2018). FBI Hate Crime Statistics https://ucr.fbi.gov.hate-crime. Accessed June 1, 2018. 
Fiorina, Morris P. (2013). "Party Homogeneity and Contentious Politics," In Can We Talk? The Rise of Rude, Nasty, Stubborn Politics, Daniel M. Shea and Morris P. Fiorina eds. New York: Pearson: 142-153.

Fiorina, Morris P., and Samuel J. Abrams. (2008). "Political Polarization in the American Public." Annual Review Political Science 11: 563-588.

Fiorina, Morris P., Samuel J. Abrams, and Jeremy Pope. (2005). Culture War? Myth of a Polarized

America. Upper Saddle River, NJ: Pearson Education.

Fischer, Karin. (2016). “The Aftermath of a 'Trump' Incident: Fear, Anger and Resolve,” The Chronicle of Higher Education, November 23, 2016.

Garand, James C. (2010). “Income Inequality, Party Polarization, and Roll-Call Voting in the US Senate.” Journal of Politics 72(04): 1109-1128.

Gelman, Andrew. (2009). Red State, Blue State, Rich State, Poor State: Why Americans Vote the Way They Do. Princeton, NJ: Princeton University Press.

Gentzkow, Matthew, and Jesse M. Shapiro. (2006). “Media Bias and Reputation.” Journal of Political Economy 114(2): 280-316.

Gerber, Alan, Dean Karlan, and Daniel Bergan. (2009). "Does the Media Matter? A Field Experiment Measuring the Effect of Newspapers on Voting Behavior and Political Opinions." American Economic Journal: Applied Economics 1(2): 35-52.

Gilens, Martin. (2012). Affluence and Influence: Economic Inequality and Political Power in America. Princeton, NJ: Princeton University Press.

Gilmour, John. (1995). Strategic Disagreement: Stalemate in American Politics. University of Pittsburgh Press. Glaeser, Edward L. (2005). “The Political Economy of Hatred,” Quarterly Journal of Economics 120(1): 45-86.

Groseclose, Timothy, and Nolan McCarty. 2001. “The Politics of Blame: Bargaining before an Audience.” American Journal of Political Science 45(1): 100-119.

Groseclose, Timothy, and Jeff Milyo. 2005. “A Measure of Media Bias.” Quarterly Journal of Economics 120(4): 1191-1237.

Hacker, Jacob S., and Paul Pierson. (2006). Off Center: The Republican Revolution and the Erosion of American Democracy. New Haven, CT: Yale University Press.

Hall, Robert L., and Frank W. Wayman. (1990). "Buying Time: Moneyed Interests and the Mobilization of Bias in Congressional Committees.” American Political Science Review 84(3): 797-820.

Hare, Christopher and Keith T. Poole. (2014). “The Polarization of Contemporary American Politics, Polity, 46(3): 411-429.

Hare, Christopher, Nolan McCarty, Keith T. Poole, and Howard Rosenthal. (2012). "Polarization is Real (and Asymmetric)." Voteview Blog. May 16, 2018. http://voteview.com/blog/?p=494.

Hirano, Shigeo, James M. Snyder, Jr., Stephen Ansolabehere, and John Mark Hansen. (2010). "Primary Elections and Partisan Polarization in U.S. Congressional Elections." Quarterly Journal of Political Science 5(2): 169-191.

James, David. (2013). "Lawmakers in Name Only? Congress Reaches Productivity Lows.” National Public Radio. Accessed on May 31, 2018. http://www.npr.org/blogs/itsallpolitics/2013/12/03/248565341/lawmakers-inname-only-congress-reaches-productivity-lows.

Jacobson, Gary C. (1990). "The Effects of Campaign Spending in House Elections: New Evidence for Old Arguments.” American Journal of Political Science 34(2): 334-362.

Jones, David R. (2014). “A More Responsible Two-Party System? Accountability for Majority and Minority Party Performance in a Polarized Congress.” Polity 46(3): 470-492.

Kaufmann, Karen M., James G. Gimpel, and Adam H. Hoffman. (2003). “A Promise Fulfilled? Open Primaries and Representation." Journal of Politics 65(2): 457-476.

Kerr, Emma. (2018). “White Supremacist Are Targeting Colleges Like Never Before,” The Chronicle of Higher Education, February 1, 2018.

Klein, Ezra. (2012). “Unpopular Mandate: Why Do Politicians Reverse Their Positions?” The New Yorker. June 2, 2018. http://www.newyorker.com/magazine/2012/06/25/unpopular-mandate. 
Klinkner, Philip A. (2004). “Red and Blue Scare: The Continuing Diversity of the American Electoral Landscape.” The Forum (2)2.

Laband, D. N. (1986). “Congressional Junketeering: Public Sector X-Inefficiency.” Journal of Economics and Business 38: 131 - 140.

Ladewig, Jeffrey W. (2014). "Polity Symposium: Partisan Polarization and American Democracy," Polity, 46(3): 407-410.

Layman, Geoffrey, and Thomas Carsey. (2002). "Party Polarization and 'Conflict Extension' in the American Electorate." American Journal of Political Science 46(4): 786-802.

Layman, Geoffrey C., Thomas M. Carsey, John C. Green, Richard Herrera, and Rosalyn Cooperman. (2010).

"Activists and Conflict Extension in American Party Politics." American Political Science Review 104(2): 324-346.

Lee, Frances. (2009). Beyond Ideology: Politics, Principles, and Partisanship in the U.S. Senate. Chicago, Illinois: University of Chicago Press.

Lenz, Gabriel S. 2012. Follow the Leader: How Voters Respond to Politicians' Policies and Performance. Chicago, Illinois: University of Chicago Press.

Lessig, Lawrence. (2011). Republic, Lost: How Money Corrupts Congress-and a Plan to Stop It. New York: Twelve/Hachette Book Group.

Levendusky, Matthew. (2009). The Partisan Sort: How Liberals Became Democrats and Conservatives Became Republicans. Chicago, Illinois: University of Chicago Press.

Levendusky, Matthew S., Jeremy C. Pope, and Simon D. Jackman. (2008). "Measuring District-Level Partisanship with Implications for the Analysis of US Elections." Journal of Politics 70(3): 736-753.

Mann, Thomas E., and Norman J. Ornstein. (2012). It's Even Worse Than It Looks: How the American Constitutional System Collided with the New Politics of Extremism. New York: Basic Books.

McCarty, Nolan, Keith T. Poole, and Howard Rosenthal. (1997). Income Redistribution and the Realignment of American Politics. Washington, DC: AEI Press.

McCarty, Nolan, Keith T. Poole, and Howard Rosenthal. (2001). "The Hunt for Party Discipline in Congress." American Political Science Review 95(3): 673-688.

McCarty, Nolan, Keith T. Poole, and Howard Rosenthal. (2006). Polarized America: The Dance of Ideology and Unequal Riches. Cambridge, Massachusetts: The MIT Press.

McCarty, Nolan, Keith T. Poole, and Howard Rosenthal. (2009). "Does Gerrymandering Cause Polarization?" American Journal of Political Science 53(3): 666-680.

McClosky, Herbert, Paul J. Hoffmann, and Rosemary O'Hara. (1960). “Issue Conflict and Consensus among Party Leaders and Followers." American Political Science Review 54(2): 406-427.

McDermont, Monika L. and Cornell Belcher. (2014). "Barack Obama and Americans' Racial Attitudes: Rallying and Polarization" Polity 46(3): 449-469.

McGhee, Eric, Seth Masket, Boris Shor, Steven Rogers, and Nolan McCarty. (2014). "A Primary Cause of Partisanship? Nomination Systems and Legislator Ideology." American Journal of Political Science. 58(2): 337-351.

Moon, Woojin. (2004). "Party Activists, Campaign Resources and Candidate Position Taking: Theory, Tests and Applications." British Journal of Political Science 34(4): 611-633.

Owoye, Oluwole, and Matthew Dabros, (2017). "The Analysis of White House Occupant and Political Polarization in the United States, Review of Social Sciences, 2(4): 1-18.

Petersen, R. Eric., Terrence L. Lisbeth, Mabel Gracias, and Parker H. Reynolds. (2010). “International Travel by Congress: Legislation in the 111th Congress, Background, and Policy Options." CRS Report R41388.

Pew Research Center. (2017). "Confidence in the U.S. President Plunges in Several Western European Countries, June 26, 2017 http://www.pewresearch.org/fact-tank/2017/06/26/around-the-world-favorability-of-u-s-andconfidence-in-its-president-decline/ft_17-06-26_us_image_europe/. Accessed on June 8, 2018.

Piketty, Thomas, and Emmanuel Saez. (2003). “Income Inequality in the United States 1913-1998." Quarterly Journal of Economics 118(1): 1-39.

Poole, Keith T. (2007). “Changing Minds? Not in Congress!” Public Choice 131:435-451 
Poole, Keith T. and Howard Rosenthal, (1984). “The Polarization of American Politics.” Journal of Politics 46(4): 1061-1079.

Prior, Markus. (2007). Post-Broadcast Democracy: How Media Choice Increases Inequality in Political Involvement and Polarizes Elections. New York: Cambridge University Press.

Quintana, Chris. (2017). "Here's a Roundup of the Latest Campus-Climate Incidents Early in the Trump Presidency," The Chronicle of Higher Education, March 15, 2017.

Rasmusen, Eric. (2007). Games and Information: An Introduction to Game Theory, 4th Edition. Malden, MA: Blackwell Publishing Limited.

Roberts, Jason M. (2007). “The Statistical Analysis of Roll-Call Data: A Cautionary Tale.” Legislative Studies Quarterly 32(3): 341-360.

Roberts, Jason M., and Steven S. Smith. (2003). "Procedural Contexts, Party Strategy, and Conditional Party Voting in the US House of Representatives." American Journal of Political Science 47(2): 305-317.

Rohde, David W. (1991). Parties and Leaders in the Postreform House. University of Chicago Press.

Rosenthal, Andrew. (2012). “Nobody Likes to Talk About It, but It's There.” The New York Times. January 3, 2018. http://takingnote.blogs.nytimes.com

Shaw, Daron. (2012). “If Everyone Votes Their Party, Why Do Presidential Election Outcomes Vary So Much?” The Forum 3(1), Article 1.

Shor, Boris, and Nolan McCarty. (2011). "The Ideological Mapping of American Legislatures.” American Political Science Review 105(3): 530-551.

Sinclair, Barbara. (2006). Party Wars: Polarization and the Politics of National Policy Making. University of Oklahoma Press.

Smith, Richard A. (1995). "Interest Group Influence in the US Congress.” Legislative Studies Quarterly 20(1): 89139.

Snyder, Jr., James M., and Tim Groseclose. (2000). “Estimating Party Influence in Congressional Roll-Call Voting." American Journal of Political Science 44(2): 193-211.

Snyder, Jr., James M., and David Stromberg. (2010). “Press Coverage and Political Accountability,” Journal of Political Economy 118(2): 355-408.

Stone, Walt J., and Elizabeth N. Simas. (2010). "Candidate Valence and Ideological Positions in US House Elections." American Journal of Political Science 54(2): 371-388.

Sulkin, Tracy and Carly Schmitt. (2014). "Partisan Polarization and Legislators' Agendas.” Polity 46(3): 430-448

Sunstein, Cass R. (2002). “The Law of Group Polarization.” Journal of Political Philosophy 10: 175-195.

Taussig, Frank W. (1931). The Tariff History of the United States: A Series of Essays, New York: G. P. Putnam's Sons.

Theriault, Sean M. (2008). Party Polarization in Congress. New York: Cambridge University Press.

Tufte, Edward R. (1973). “The Relationship between Seats and Votes in Two-Party Systems.” American Political Science Review 67(2): 540-554.

Weil, David N. (2013). Economic Growth, Addison-Wesley/Pearson Publisher.

Woodward, Vann C. (2002). The Strange Career of Jim Crow, 1955, New York: Oxford University Press.

Zoellick, R. B. (1999). “Congress and the Making of U.S. Foreign Policy.” Survival 41: 20-41. 